\title{
LETTER \\ The Largest Subunit of Human RN A Polymerase III Is Closely Related to the Largest Subunit of Yeast and Trypanosome RN A Polymerase III
}

\author{
Setareh Sepehri ${ }^{1,2}$ and Nouria Hernandez ${ }^{1,3,4}$
}

${ }^{1}$ Cold Spring Harbor Laboratory and ${ }^{3}$ Howard Hughes Medical Institute, Cold Spring Harbor, New York 11724; ${ }^{2}$ Department of Microbiology, State University of New York at Stony Brook,

Stony Brook, New York 11794

In both yeast and mammalian systems, considerable progress has been made toward the characterization of the transcription factors required for transcription by RNA polymerase III. However, whereas in yeast all of the RNA polymerase III subunits have been cloned, relatively little is known about the enzyme itself in higher eukaryotes. For example, no higher eukaryotic sequence corresponding to the largest RNA polymerase III subunit is available. Here we describe the isolation of CDNAs that encode the largest subunit of human RNA polymerase III, as suggested by the observations that (1) antibodies directed against the cloned protein immunoprecipitate an active enzyme whose sensitivity to different concentrations of $\alpha$-amanitin is that expected for human RNA polymerase III; and (2) depletion of transcription extracts with the same antibodies results in inhibition of transcription from an RNA polymerase III, but not from an RNA polymerase II, promoter. Sequence comparisons reveal that regions conserved in the RNA polymerase I, II, and III largest subunits characterized so far are also conserved in the human RNA polymerase III sequence, and thus probably perform similar functions for the human RN A polymerase III enzyme.

[The sequence data described in this paper have been submitted to the GenBank data library under accession no. A F021351]

In eukaryotes, transcription is carried out by three major forms of DNA-dependent RNA polymerases, RNA polymerase I, RNA polymerase II, and RNA polymerase III. Each is responsible for transcription of particular sets of genes: Thus, RNA polymerase III transcribes a number of small cellular genes including those encoding the ribosomal 5S RNA, the tRNAs, the U6 small nuclear RNA (snRNA), the mitochondrial RNA processing (MRP)/Th RNA, which is involved in the processing of the primer required for mitochondrial replication (Topper and Clayton 1990), the H1 RNA, a component of RNase P (Baer et al. 1989), the hY RNAs, which are components of the Ro particles (Wolin and Steitz 1983), and the 7SK RNA (Murphy et al. 1986), of unknown function. This enzyme al so transcribes several small viral

${ }^{4}$ Corresponding author.

E-MAIL hernande@cshl.org; FAX (516) 367-6081. genes such as the adenovirus 2 ( $\mathrm{Ad} 2$ ) VAl gene. None of the RNA polymerases can recognize their target promoters directly but, instead, require accessory transcription factors that bind to the promoters and mediate polymerase recruitment. Considerable efforts have been directed toward the characterization of the transcription factors required by the three RNA polymerases. In addition, in yeast, the RNA polymerases themselves are well characterized and CDNAs corresponding to the large majority of their subunits have been isolated (for review, see Sentenac et al. 1992; Thuriaux and Sentenac 1992). Less is known, however, about the mammalian enzymes, in particular RNA polymerase III.

In Escherichia coli, transcription is carried out by a single RNA polymerase. The core enzyme consists of four subunits, the largest $\beta^{\prime}$ subunit, the second largest $\beta$ subunit, and two copies of the $\alpha$ subunit. Together, these subunits form a tetrameric complex that requires the $\sigma$ factor for specific promoter rec- 
ognition (for review, see Chamberlin 1994; Chan and Landick 1994). As in E. coli, transcription in archaebacteria is carried out by a single RNA polymerase, but the enzyme is more complex and consists of more subunits than the E. coli enzyme (for review, see Baumann et al. 1995). The eukaryotic RNA polymerases are multisubunit enzymes very similar to the archaebacterial enzymes, containing 13-17 subunits in yeast. The two largest RNA polymerase I, II, and III subunits have been cloned from a number of organisms. For example, the largest subunits from all three enzymes have been cloned from Saccharomyces cerevisiae (Allison et al. 1985; Memet et al. 1988a) and Trypanosoma brucei (Evers et al. 1989; Smith et al. 1989b). In addition, the largest subunit of RNA polymerase III has been cloned from Plasmodium falciparum (Li et al. 1991) and Giardia Iamblia (Lanzendoerfer et al. 1992), but unlike the largest subunit of RNA polymerase II, for which the human (Wintzerith et al. 1992), Mus musculus (Ahearn et al. 1987), Caenorhabditis elegans (Bird and Riddle 1989), D rosophila melanogaster (Jokerst et al. 1989), and Arabidopsis thaliana (Dietrich et al. 1990) sequences are available, no RNA polymerase III largest subunit sequence is available from a higher eukaryote.

Comparison of the available amino acid sequences reveals that the largest and second largest subunits are very conserved among the three eukaryotic RNA polymerases and that each is homologous to polypeptides in archaebacteria: Thus, the first two-thirds of the largest subunit are homologous to the A polypeptide and the last third to the $C$ polypeptide of the archebacterium Halobacterium halobium, whereas the second largest subunit is homologous to the $B$ polypeptide of this organism (Leffers et al. 1989; Puhler et al. 1989). Moreover, the largest and second largest subunits are homologous to the $\beta^{\prime}$ and $\beta$ subunits, respectively, of the E. coli enzyme. The largest subunit contains eight highly conserved regions, referred to as regions a to $\mathbf{h}$ (Jokerst et al. 1989; Sentenac et al. 1992). Of these, all are conserved in $H$. halobium A or $C$ polypeptides, and six (regions $\mathbf{b}, \mathbf{c}, \mathbf{d}, \mathbf{f}, \mathbf{g}$, and $\mathbf{h}$ ) are conserved in the $\mathrm{E}$. coli $\beta^{\prime}$ subunit (Allison et al. 1985; Memet et al. 1988b; Jokerst et al. 1989).

The roles of the various conserved regions are not yet fully understood, but a number of mutational and cross-linking studies in both the E. coli and the eukaryotic enzymes suggest that several of the conserved regions in the two largest subunits of RNA polymerase cooperate in the formation of a cleft containing the active site of the enzyme, that is, the binding sites for the incoming ribonucleoside triphosphates, the template, and the nascent RNA (for review, see Sentenac et al. 1992; Thuriaux and Sentenac 1992). For example, the $\mathbf{c}$ region contains a weak similarity to a region in both T7 DNA polymerase and E. coli DNA polymerase I (Allison et al. 1985), which in the E. coli DNA polymerase is part of the DNA binding cleft (Ollis et al. 1985a,b). This suggests that the $\mathrm{c}$ region in the RNA polymerases may contact nucleic acids and thus be part of the active site. The $\mathbf{d}$ region contains the motif (Y/F)NADFDGD(E/Q)M(N/A), which is invariant in all multimeric RNA polymerases and constitutes the $\mathrm{Mg}^{2+}$ binding site of the $\mathrm{E}$. coli enzyme (Zaychikov et al. 1996). The $f$ region is the site of all known mutations that confer resistance to $\alpha$-amanitin (Bartolomei and Corden 1987, 1995; Chen et al. 1993) a toxin that inhibits transcription elongation (Cochet-Meilhac and Chambon 1974; de Mercoyrol et al. 1989), and mutations in this region affect transcription elongation (Coulter and Greenleaf 1985; Thuillier et al. 1996). In the E. coli enzyme, the $\mathbf{g}$ region can be crosslinked to the $3^{\prime}$ end of the nascent RNA (Borukhov et al. 1991).

Other conserved regions, such as the a region, may play a role in the heteromultimeric assembly of the enzyme. This region contains a zinc-binding domain with the consensus $\mathrm{CX}_{2} \mathrm{CX}_{6-12} \mathrm{CXGHXG-}$ $X_{24-37} C X_{2} C$. In yeast, mutants in the conserved residues of the consensus zinc-binding domain of the RNA polymerase III largest subunit are not viable, and conditional mutants of this region form an unstable enzyme lacking three RNA polymerase IIIspecific subunits, C82, C34, and C32 (Werner et al. 1992).

As a first step toward the characterization of human RNA polymerase III, we report the cloning of its largest subunit. We show that antibodies directed against the cloned protein immunoprecipitate an active enzyme with the $\alpha$-amanitin sensitivity diagnostic of human RNA polymerase III. Furthermore, depletion of transcription extracts with these antibodies results in decreased transcription from the RNA polymerase III VAI but not from the RNA polymerase II Ad2 major late promoter. Alignment of the sequence with the largest subunits of yeast and trypanosome RNA polymerase III, the largest subunits of RNA polymerases I and II from various organisms, the $\mathrm{H}$. halobium $A$ and $C$ polypeptides, and the E. coli $\beta^{\prime}$ subunit confirms that the largest subunit of RNA polymerases has remained highly conserved through evolution. 


\begin{abstract}
MVKEQFRETDVAKKTSHICF GMKSPEEMRQQAHIQVVSKN LYSQDNQHAPLLYGVLDHFM 60 GTSEKDRPCETCGKNLADCL GHYGIDLELPCFHVGYFRA VIGILOMICKTCCHIMLSOE 120 EKKQFLDYLKRPGLTYLQKR GLKKKISDKCRKKNICHHCG AFNGTVKKCGT,TKTTHEKYK 180 TNKKWDPIVSNFLQSFETA IEHNKEVEPLLGRAQENLNP LVVLNLFKRIPAEDVPLLLM 240 WPEAGKPSDLILTRLLLVPL_CFRDSVVSDLKSGTNEDDLI' MKLIEI IF'LNDVIKKHRISC 30 AKTOMIMEDWDFLQLOCALY INSELSGIFLMMAPKKWTRG FVORLKGKOGRFRGNLSGKR 360 VDESGRTVISPDPNIRIIDEV AVVPVHVAKILTFPEKVNKAN TNFIRKTIVONGPEVHPGANF 420

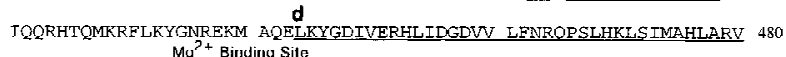
KPHRTFRENECVCTPYNADF DGDEMINLLLPOTEEAKAEAL VLMG'L'KANLVI'PRNGEPLIA 540 ALONFLTGAYLLTLKDTFFD RAKACOIIASILVGKDEKIK VRLPEETILRPVTLWTGKOI 600 FSVILRPSDDNPVRANLRTK GKQYCGKGEDLCANDSYVTI QNSELMSGSMDKGTTGSGSK NNTFYTTLLRWGQNEAADAM SRLARLAPVYLSNRGESIGI GDVTPGQGLLKAKYELLNAG 720 YKKCDEYIEALNTGKLQQQF GCTAEETIEALILKELSVIR DHAGSACLRELDKSINSPLTM 780 ALCGSKGSFINISOMIICVG DONISGSRVPDOFENRSLPH FEKHSKLPAAKGFVANSFYS 840 GLTFTEFPFHTMAGREGLVD TAVKTAETGMMORRLVKSLE DLCSOYDLTVRSSTGDTTOF $90 \%$ IYGG]MGIII PAAMH:LKIJH:PLE FKRVLDNIKAVFPCPSEPAL SKNELILTTESIMKKSEFLC 960 CODSFLQEIKKFIKGVSEKI KKTRDKYGINDNGTTEPRVL YQLDRITPTQVEKFLETCRD 1020 KYMRAQMEPGSAVGALCAOS IGEPGTOMTLKTFHFGGVAS MNITLGVRRIKEIINASKAI U(\%) STPIITAQLDKDDDADYARL VKGRIEK'LLLGELISEYTIEEV FT,PNDCFILVKLSLERIRLL 1140 KLEVVAETVRYSICTSKLRV KFGDVAVHGEAVVCVTEREN SKSSMYYVLOFLKEDLFKVV 1200 VQGIFEVSRAVIHIDEQSGK EKYKLLVEGDNLRAVMATHG VKGTRTTSNNTYEVEKTLGI 1260 EAARTTIINETOYTMVINHG MSIDRRHVMLLSDLMTYKGE VLGITRFGLAKMKESVLMLA 1320 SFEKTADHLFDAAYFGOKDS VOGVSECI IMGI PMINIGTGL FKLLHKADKDPNNEKRPLIF 1380 DINEFHIPLVT
\end{abstract}

Figure 1 Predicted amino acid sequence of hRPC155. The conserved $\mathbf{a}-\mathbf{h}$ regions are underlined. The consensus $\mathrm{Zn}^{2+}$ binding domain in the a region is indicated in bold letters. The locations of the similarity to the helix J-turn-helix $\mathrm{K}$ motif present in E. coli DNA polymerase I and T7 DNA polymerase, and of the $\mathrm{Mg}^{2+}$ binding site, are indicated. The boxed amino acids at the carboxyl terminus of hRPC155 correspond to the synthetic peptide $\mathrm{CSH}-499$ that was used to raise the anti-hRPC155 antibody (antibody $\alpha$-CSH499, rabbit CS377).

\section{RESULTS A N D DISCUSSIO N}

Isolation of CDN A s Encoding the Largest Subunits of Human RN A Polymerase III

To isolate the largest subunit of human RNA polymerase III, we took advantage of the sequence conservation among the RNA polymerase III largest subunits of different species to design degenerate oligonucleotides for use in PCRs. From a combination of PCRs and CDNA library screens (see Methods for details), we isolated a cDNA containing an open reading frame (ORF) encoding the 1391 amino acid polypeptide shown in Figure 1, with a calculated molecular mass of $154.7 \mathrm{kD}$ and a pl of 8.54. We refer to this polypeptide as hRPC 155 .

We compared the predicted amino acid sequence with that of the largest RNA polymerase III subunit of yeast and trypanosome, the largest RNA polymerase II subunit of man, mouse, fly, worm, yeast, and trypanosome, the largest RNA polymerase I subunit of yeast and trypanosome, the $A$ and $C$ polypeptides of the archaebacterium $\mathrm{H}$. halobium, and the $\beta^{\prime}$ subunit of $E$. coli with the program CLUSTAL W (v. 1.6) (Thompson et al. 1994). As shown in the phylogenetic tree in Figure 2, the sequence is most related to the RNA polymerase III largest subunits of other species, with $50 \%$ and $40 \%$ identities to the $\mathrm{S}$. cerevisiae and $\mathrm{T}$. brucei enzymes, respectively. In contrast, the hRPC 155 sequence is only $32 \%$ identical with human RNA polymerase II and $22 \%-27 \%$ identical with the available RNA polymerase I sequences. This is consistent with hRPC155 corresponding to the largest subunit of human RNA polymerase III. As noted previously (Memet et al. 1988a), the RNA polymerase II and III

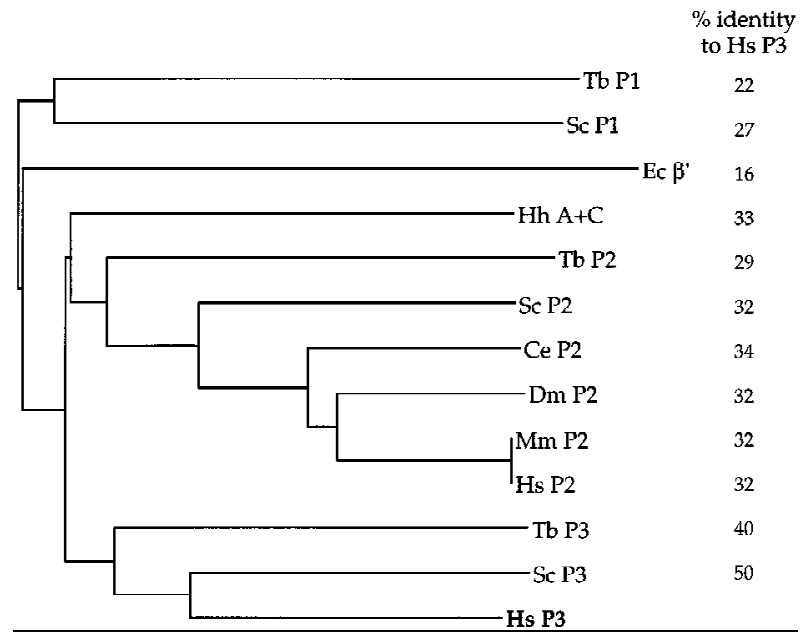

Figure 2 Evolutionary conservation of largest RNA polymerase subunits. Sequences from the largest subunits of the indicated RNA polymerases were aligned with the CLUSTAL W (v. 1.6) program (Thompson et al. 1994) with the default parameter settings. The percentages of amino acids identical between the human RNA polymerase III sequence and the various largest subunits are indicated on the right. P1, P2, and P3 refer to RNA polymerases I, II, and III, respectively. The references for the sequences are as follows: E. coli (EC) $\beta^{\prime}$ (Ovchinnikov et al. 1982); H. halobium (Hh) A and C polypeptides (Leffers et al. 1989); T. brucei (Tb) P2 (Smith et al. 1989a); S. cerevisiae (Sc) P2 (Allison et al. 1985); C. elegans (Ce) P2 (Bird and Riddle 1989); D. melanogaster (Dm) P2 (Jokerst et al. 1989); M. musculus (M m) P2 (Ahearn et al. 1987); human (Hs) P2 (Wintzerith et al. 1992); Tb P3 (Smith et al. 1989a); Sc P3 (Allison et al. 1985); Tb P1 (Smith et al. 1989a); Sc P1 (Memet et al. 1988). 


\section{CLONING OF HUMAN RNA POLYMERASE III LARGE SUBUNIT}

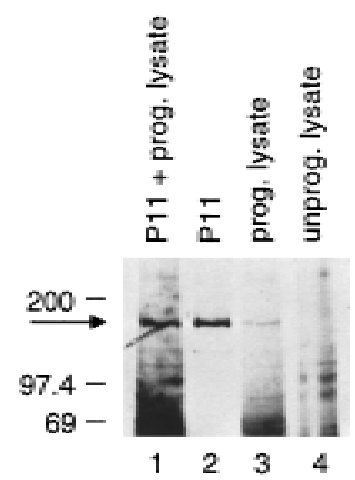

Figure 3 The polypeptide encoded by the cloned CDNA comigrates with endogenous hRPC155. The immunoblot was probed with the $\alpha-\mathrm{CSH} 499$ antibody. (Lane 1) Mixture of $5 \mu \mathrm{l}$ of P11 fraction (see Methods) and $5 \mu$ l of programmed reticulocyte lysate; (lane 2) 10 $\mu$ of P11 fraction; (lanes 3, 4) $5 \mu$ l of programmed and nonprogrammed reticulocyte lysate, respectively. After decay of the chemiluminescent signal, the membrane was exposed to a second film for visualization of the $\left.\mathrm{L}^{35} \mathrm{~S}\right]$ methionine-labeled in vitro-translated proteins. The outline of the membrane, which was visible on both film exposures, was then used as a guide to overlay the two films. The ${ }^{35} \mathrm{~S}$ signals present in lanes 1 and 3 (but not in lanes 2 and 4 ) could be superimposed exactly onto the chemiluminescent signals, as expected.

largest subunits are more closely related to each other than to the RNA polymerase I largest subunit. In addition, the $\mathrm{H}$. halobium $\mathrm{A}$ and $\mathrm{C}$ polypeptides are most closely related to the eukaryotic largest subunits, with the RNA polymerase II largest subunits being the most similar.

Recombinant hRPC 155 Comigrates with the Largest Subunit of HeLa Cell RN A Polymerase III

The ORF shown in Figure 1 contains a homology to the a region of other RNA polymerase largest subunits preceded by a methionine, suggesting that it might encode the full-length hRPC 155. To verify this assumption, we raised rabbit polyclonal antibodies against a peptide derived from the carboxyl terminus of the predicted ORF (see Fig. 1) and used this antibody ( $\alpha$-CSH 499) in immunoblots. As shown in Figure 3, the polypeptide translated in vitro from the isolated cDNA (lane 3) comigrates with a polypeptide detected by the antibody in a fraction enriched in RNA polymerase III (P11 fraction) (lane 2; see also lane 1). This further suggests that the predicted ORF corresponds to the fulllength protein.
The anti-hRPC155 A ntibody Immunoprecipitates an A ctive Enzyme with a Sensitivity to $\alpha$-amanitin Typical of Mammalian RNA Polymerase III

We determined whether the anti-hRPC155 antibody could recognize the largest RNA polymerase III subunit as part of an active enzyme by performing immunoprecipitations from two fractions enriched in RNA polymerase III, an ammonium sulfate cut (data not shown) and a P11 fraction (see M ethods), with both preimmune antibodies and antihRPC155 antibodies. Material bound to the antibodies was eluted with either the specific peptide against which the antibody was raised or with a nonspecific peptide, and the eluted material was tested in a nonspecific transcription assay (Roeder 1974) in the presence of various concentrations of $\alpha$-amanitin. As shown in Figure 4, no significant RNA polymerase activity was eluted from the preimmune beads, or with the nonspecific peptide. However, significant RNA polymerase activity was eluted from the anti-hRPC155 beads with the specific peptide, and this activity was resistant to low,

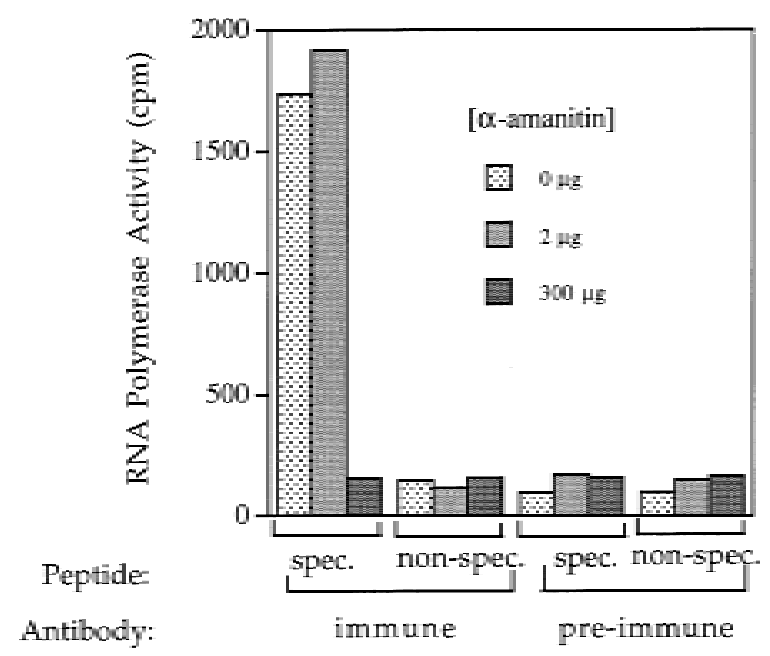

Figure 4 An antibody directed against hRPC155 immunoprecipitates an RNA polymerase III active in a nonspecific transcription assay. Immunoprecipitations were performed as detailed in Methods with preimmune or anti-hRPC155 (antibody $\alpha$-CSH499, rabbit CS-377) antibodies and P11 fraction. Antibody-bound material was eluted with specific or nonspecific peptide and tested in a nonspecific transcription assay as described in Methods, in the absence or presence of 2 or $300 \mu \mathrm{g} / \mathrm{ml}$ of $\alpha$-amanitin. The data are represented as total amounts of cpm retained on DE81 cellulose filters in the nonspecific transcription assay. Approximately $30 \%$ of the activity resistant to $2 \mu \mathrm{g} / \mathrm{ml}$ of $\alpha$-amanitin was recoved in the specific immunoprecipitation. 


\section{SEPEHRI AND HERNANDEZ}

but not to intermediate, concentrations of $\alpha$ amanitin. Thus, an antibody directed against the carboxyl terminus of the cloned polypeptide could precipitate an active RNA polymerase with the pattern of resistance to various levels of $\alpha$-amanitin typical of human RNA polymerase III. This confirms that the polypeptide wecloned is the largest subunit of RNA polymerase III and suggests that the carboxyl terminus of this polypeptide is accessible to the antibody in the active enzyme.

Depletion of Transcription Extracts with the A nti-hRPC 155 A ntibody Specifically Inhibits Transcription from an RN A Polymerase III Promoter

To determine whether the anti-hRPC155 antibody could recognize an enzyme involved in specific transcription from RNA polymerase III promoters, we depleted a transcription extract with either preimmune or anti-hRPC 155 beads and tested in parallel transcription from the Ad2 VAI RNA polymerase III promoter and the Ad2 major late RNA polymerase II promoter. As shown in Figure 5, incubation of the extract with anti-hRPC 155 beads had no greater effect on transcription from the Ad2 major late promoter than incubation with preimmune antibodies (cf. lanes 2 and 3, bottom). In contrast, however, incubation with the anti-hRPC155 beads but not the preimmune beads reduced VAl transcription, and this effect was blocked by preincubation of the antibodies with the specific peptide against which they were raised, but not by preincubation with a nonspecific peptide (lanes 2-5, top). There is, however, residual VAl transcription after anti-hRPC155 depletion, consistent with the observation that the depletion of RNA polymerase III was not quantitative as determined by immunoblot (data not shown). Nevertheless, these results indicate that the antibodies recognize, and are specific for, an enzyme that is active for specific transcription from RNA polymerase III promoters.

\section{Sequence Conservation in V arious RN A Polymerases}

The isolation of the hRPC 155 cDNA provides the opportunity to compare a higher eukaryote RNA polymerase III largest subunit with the already cloned RNA polymerase largest subunits and to determine how well the previously observed sequence conservations hold. Figure 6 is a schematic diagram showing the location of the conserved regions a-h in hRPC 155. Below the diagram we indicate the percentage identity between hRPC155 and other eu-

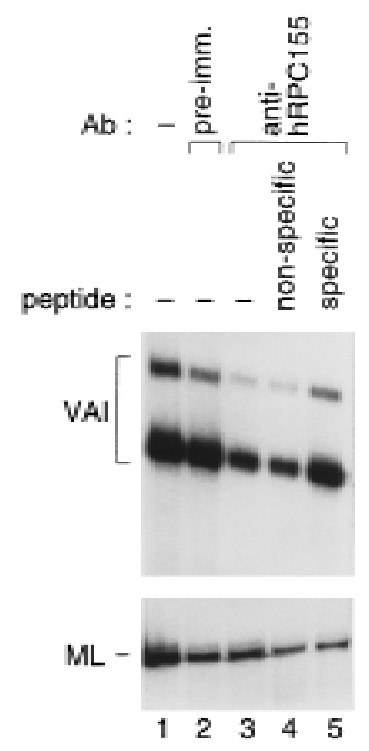

Figure 5 Depletions of a transcription extract with the anti-hRPC155 antibody specifically reduce transcription from the VAl promoter. Whole cell extract was incubated with preimmune (lane 2) or antihRPC155 (lanes 3-5) beads with either no peptide (lane 2,3) or specific (peptide CHS499, lane 5) or nonspecific (peptide CSH498, lane 4) peptide, as detailed in Methods. Aliquots of nontreated (lane 1) or the variously treated extracts were then tested for transcription from the Ad2 VAl promoter (top) or the Ad2 major late promoter (bottom). The signals corresponding to correct initiation from the VAl or major late (ML) promoters are indicated. Immunoblots indicated that extract treated with the specific antibody contained $\sim 50 \%$ of the hRPC155 present in extract treated with the preimmune antibodies (data not shown).

karyotic sequences, the $E$. coli $\beta^{\prime}$ sequence, and the $H$. halobium $A$ and $C$ sequences, in these regions. With the exception of the $\mathbf{b}$ and $\mathbf{h}$ regions, where the human $\mathrm{hRPC} 155$ sequence is less related to the largest RNA polymerase III subunit of $\mathrm{T}$. brucei than to RNA polymerase II largest subunits, regions a-g are more related to the largest RNA polymerase III subunit of species as distant as S. cerevisiae and T. brucei than to the largest human RNA polymerase II subunit. The $\mathbf{b}$ region is in general approximately equally conserved among the RNA polymerase II and III largest subunits, and the e region, which is also the most conserved region, is approximately equally conserved among the three eukaryotic RNA polymerase largest subunits. The conservation between the $\mathbf{a}-\mathbf{h}$ regions of the eukaryotic largest subunits and the archaebacterial $A$ and $C$ polypeptides is striking: Except for the e region, which is only $25 \%$ identical to the e region of hRPC155, all re- 


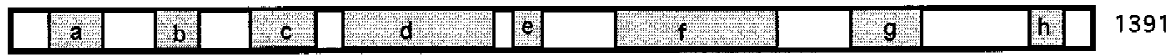

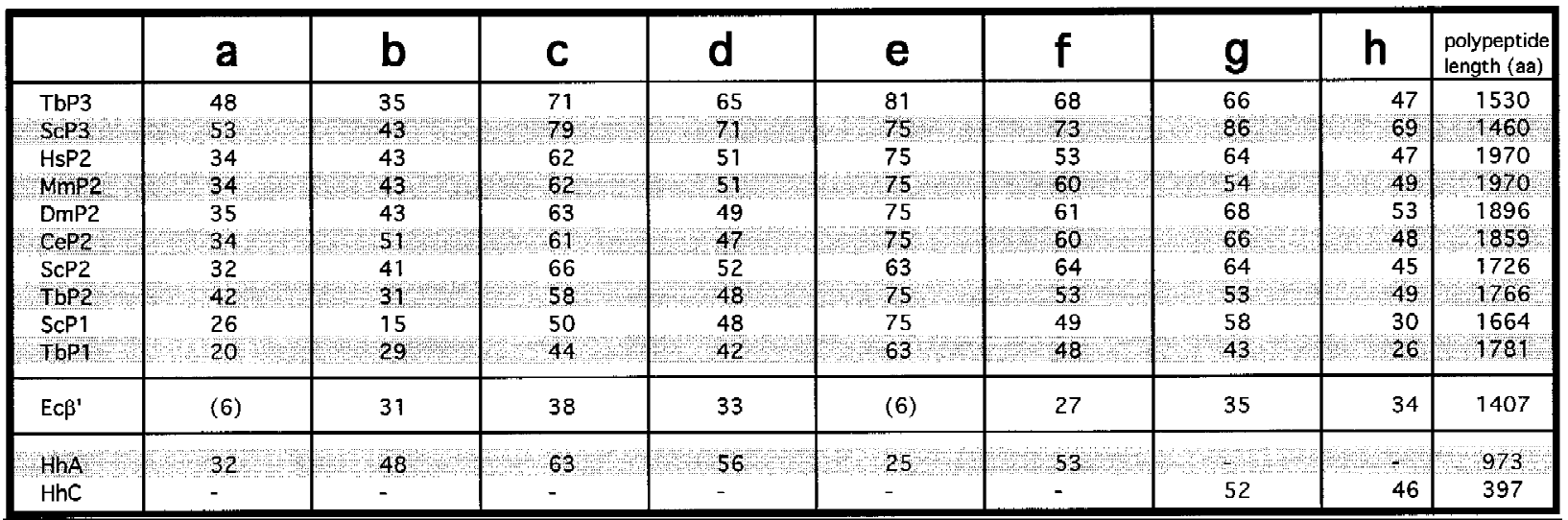

Figure 6 The $\mathbf{a}-\mathbf{h}$ regions are highly conserved among RNA polymerases. The percentages of identical amino acids between the human RNA polymerase III sequence and various eukaryotic largest subunits, the E. coli $\beta^{\prime}$ subunit, and the $\mathrm{H}$. halobium $A$ and $C$ polypeptides within the conserved regions $\mathbf{a}-\mathbf{h}$ are indicated. The numbers on the right indicate the total length of the polypeptide. P1, P2, and P3 refer to RNA polymerases I, II, and III, respectively.

gions are at least $32 \%$ conserved. The E. coli se quence is less conserved, with no significant homology to hRPC155 in the a and e regions.

Figure 7 shows sequence alignments of the $\mathbf{a}-\mathbf{h}$ regions of eukaryotic largest subunits and the $\mathrm{H}$. halobium A and C polypeptides, and, where indicated, flanking sequences (overlined). In E. coli, a screen identified mutations in the conserved $\mathbf{c}, \mathbf{f}, \mathbf{g}$, and $\mathbf{h}$ regions of the $\beta^{\prime}$ sequence, implicating all of these regions in transcription elongation and termination (Weilbaecher et al. 1994). We have therefore also included the $\beta^{\prime}$ sequence in the alignments of these regions, as well as in the alignment of the $\mathbf{d}$ region.

The $\mathbf{a}, \mathbf{b}, \mathbf{c}$, and $\mathbf{d}$ Regions

In the a region the consensus $\mathrm{CX}_{2} \mathrm{CX}_{6-12}$

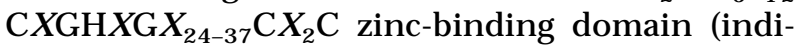
cated by bold letters in the al ignment) is completely conserved in hRPC 155, consistent with studies in yeast RNA polymerase III, where mutations of the conserved residues in the consensus sequence are lethal (Werner et al. 1992). The b region is quite conserved in all RNA polymerase II and III largest subunits, but more divergent in the RNA polymerase I largest subunits and the $\mathrm{H}$. halobium A polypeptide.
In the c region alignment, we included the sequences from E. coli DNA polymerase I and T7 DNA polymerase noted previously as showing weak homology to RNA polymerases (Allison et al. 1985). The residues that are similar or identical in the T7 and E. coli DNA polymerases and in the human RNA polymerase III largest subunit are marked by a coIon. The largest subunit of human RNA polymerase III is as related to this region of the DNA polymerases as the largest subunit of yeast RNA polymerases II and III (Allison et al. 1985), with most of the similarities lying upstream of the helix-turn-helix motif, in the loop between $\beta$-sheet 7 and 8 , in $\beta$-sheet 8 , and in the loop separating $\beta$-sheet 8 and helix J, a region that lines the DNA-binding cleft of $E$. coli DNA polymerase (Ollis et al. 1985a). In the E. coli sequence, the residues that are shaded and underlined correspond to residues that were altered in the screen for mutations affecting E. coli RNA polymerase transcription termination (Weilbaecher et al. 1994). Those located upstream or within the similarity to the DNA polymerases are identical or simiIar in the human RNA polymerase III largest subunit sequence. This is consistent with the proposed role of the region in contacting the DNA template and/ or the RNA transcript.

In the alignment of the $\mathbf{d}$ region, we also show 
the $E$. coli $\beta^{\prime}$ region of similarity. This region contains the (Y/F)NADFDGD(E/Q)M (N/A) motif, which has so far been found in all multimeric RNA polymerases, including the archaebacterial enzymes (Dieci et al. 1995). Recently, the three aspartates in the (Y/F)NADFDGD(E/Q)M(N/A) motif have been shown to constitute the $\mathrm{Mg}^{2+}$ binding site of the $\mathrm{E}$. coli enzyme (Zaychikov et al. 1996). The motif is conserved in the human RNA polymerase III largest subunit. The $\mathbf{d}$ region has been mutagenized extensively in the yeast largest RNA polymerase III subunit, leading to the isolation of a number of lethal singlesite substitutions and a few conditional mutants (Dieci et al. 1995). The positions of the lethal substitutions are shaded and underlined in the S. cerevisiae sequence, and all of them are identical in the human RNA polymerase III largest subunit sequence. Similarly, the positions of conditional mutants in S. cerevisiae (overlined) are identical in the human sequence with the exception of a R528 in the yeast sequence to a $K 516$ conservative change in the human sequence. The conditional double substitution T506/N509 in yeast affects mainly elongation rates but not transcription complex formation or initiation (Dieci et al. 1995). The conservation of the human sequence in this region is consistent with the view that the $\mathbf{d}$ region is part of the active site of the enzyme (Dieci et al. 1995; Zaychikov et al. 1996).

In the largest subunit of S. cerevisiae RNA polymerase II, both the $\mathbf{c}$ and $\mathbf{d}$ regions have been implicated in start site selection (Berroteran et al. 1994). Thus, sua8 suppressors, which suppress an aberrant ATG translation initiation codon in the leader region of the cycl gene by favoring transcription initiation at downstream sites, alter A402 in the c region and $\mathrm{N} 445$ in the $\mathbf{d}$ region (residues shaded and underlined) of the $\mathrm{S}$. cerevisiae RNA polymerase II largest subunit. Both positions are conserved in the human RNA polymerase III sequence and in all eukaryotic and archaebacterial RNA polymerase sequences (Fig. 6; data not shown). The phenotypes of the sua8 suppressors are very similar to the phenotypes of the sua7 suppressors, which encode altered forms of TFIIB, and the sua 7 and sua8 mutations are synthetic lethal, suggesting an interaction between TFIIB and RNA polymerase II, perhaps a direct interaction between TFIIB and the RNA polymerase II largest subunit (Berroteran et al. 1994). Human TFIIB interacts directly with RNA polymerase II in vitro through its two direct repeats (Ha et al. 1993), but the site of interaction in RNA polymerase II has not been determined. However, the conservation of the sua8 positions in all RNA polymerases would then suggest equivalent interactions of RNA polymerases I and III with one of their transcription factors. Transcription initiation by RNA polymerase III requires $B R F$, the TFII $B$-related factor (also called TDS4, PCF4, and TFIIIB90), and both the yeast and human BRF are quite similar to TFIIB in the two repeat regions (Buratowski and Zhou 1992; Colbert and Hahn 1992; López-De-León et al. 1992; Wang and Roeder 1995; Mital et al. 1996). Although BRF has been shown to interact directly with the RNA polymerase III-specific C34 subunit (Khoo et al. 1994) and with a subcomplex consisting of the RNA polymerase III C32, C34, and C82 subunits (Werner et al. 1993), there is no evidence so far of a direct contact with the largest RNA polymerase III subunit. In addition, no counterpart of TFIIB and BRF has yet been isolated for RNA polymerase I transcription. The sua 8 suppressors may thus affect the TFIIB-RNA polymerase II interaction indirectly.

\section{The $\mathbf{e}$ and $\mathbf{f}$ Regions}

The e region is highly conserved in eukaryotic largest subunits, but the conservation in $\mathrm{H}$. Halobium is poor, and we therefore show the $\mathrm{H}$. halobium sequence below the alignment of the eukaryotic sequences. The $\mathbf{f}$ region and the region upstream are the sites of a number of mutations in different RNA polymerases from different organisms that affect transcription elongation. In the E. coli $\beta^{\prime}$ subunit, mutations at the shaded and underlined positions alter transcription termination (Weilbaecher et al. 1994). Most of these positions are identical in the human RNA polymerase III largest subunit. In the yeast RNA polymerase III largest subunit, the shaded and underlined residues indicate the positions of lethal or conditional (in lowercase letters) single, double, or triple substitutions (Thuillier et al. 1996). The double conditional mutant D829/R830 has been shown to affect transcription elongation but not transcription complex assembly nor formation of the first phosphodiester bond (Thuillier et al. 1996). Within the region, most of the positions are identical in the human RNA polymerase III largest subunit sequence. The conservation is less good upstream of the region. In particular, a putative RNA polymerase III-specific motif (Smith et al. 1989a), indicated by bold letters upstream of region $\mathbf{f}$, is not any more conserved among the RNA polymerase III sequences than among all RNA polymerase sequences. This region is more an RNA polymerase II-specific motif, with the second position an asparagine in all RNA polymerase II sequences.

A number of mutations that render RNA poly- 
merase II more resistant to $\alpha$-amanitin have been mapped to the $\mathbf{f}$ region in M. musculus (Bartolomei and Corden 1987, 1995), D. melanogaster (Chen et al. 1993), and C. elegans (in Chen et al. 1993). In D. melanogaster, one of these mutations (C4 mutation $\mathrm{R} 741 \mathrm{H}$ ) has been shown to alter the transcription elongation properties of the enzyme in vitro (Coulter and Greenleaf 1985). The positions of all these mutations are shaded and underlined in the corresponding sequences. Most of these positions are al so conserved in the human RNA polymerase III largest subunit sequence, suggesting that they are part of an $\alpha$-amanitin binding pocket but do not confer the differential sensitivities to $\alpha$-amanitin of the different RNA polymerases. However, there is onestriking exception. N792 in the mouse sequence (bold, shaded, and underlined) is conserved in the RNA polymerase II enzymes except for the yeast enzyme (Bartolomei and Corden 1995), which is 100fold more resistant to $\alpha$-amanitin than the verte- brate enzyme (see Schultz and Hall 1976) and is not conserved in any of the $\alpha$-amanitin-resistant enzymes including human RNA polymerase III. Thus, an $\mathrm{N}$ at this position may contribute to the formation of a high affinity binding site for $\alpha$-amanitin and therefore result in high sensitivity to the toxin.

\section{The $\mathbf{g}$ and $\mathbf{h}$ Regions}

Like regions $\mathbf{c}$ and $\mathbf{d}$, regions $\mathbf{g}$ and $\mathbf{h}$ have been implicated in both transcription initiation and elongation. The $\mathbf{g}$ region is implicated in transcription initiation because it is the site of two mutations in S. cerevisiae RNA polymerase II, T1080I and S1096F, that result in slightly altered start sites at the HIS4 promoter (Hekmatpanah and Young 1991), whereas the $\mathbf{h}$ region contains the site mutated (position G1388, shaded and underlined) in a sua8 suppressor (Berroteran et al. 1994). One of the two residues mutated in the $\mathrm{g}$ region (T1080) is con-

Figure 7 Sequence alignment of the conserved regions $\mathbf{a}-\mathbf{h}$ of various largest subunits (see $\mathrm{p}$. 1014-1015). The sequence alignments were performed with the CLUSTAL W (v. 1.6) program (Thompson et al. 1994) with the default parameter settings, except for the alignments of the $E$. coli $\beta^{\prime}$ subunit in the $\mathbf{c}, \mathbf{f}, \mathbf{g}$, and $\mathbf{h}$ regions, which were according to Weilbaecher et al. (1994). Asterisks $(*)$ indicate identities in the 11 eukaryotic sequences; pluses (+) indicate at least 11 out of 12 similarities or identities. The following amino acids were considered similar: V, I, $\mathrm{L}$, and $\mathrm{M} ; \mathrm{D}$ and $\mathrm{E} ; \mathrm{N}$ and $\mathrm{Q} ; \mathrm{R}, \mathrm{K}$, and $\mathrm{H} ; \mathrm{S}$ and $\mathrm{T} ; \mathrm{W}, \mathrm{F}$, and $\mathrm{Y}$. The numbers in parentheses correspond to the first and last amino acids of the sequence shown. The abbreviations for the various organisms are as in Fig. 2 . The overlined sequences in regions $\mathbf{c}, \mathbf{f}$, and $\mathbf{h}$ are not part of the conserved regions and were not included in the percent calculations in Fig. 6 . The shaded and underlined residues in the E. coli (EC) $\beta^{\prime}$ sequences in regions $\mathbf{c}, \mathbf{f}, \mathbf{g}$, and $\mathbf{h}$ correspond to the locations of mutations that affect transcription termination (Weilbaecher et al. 1994). In region $\mathbf{a}$, the conserved amino acids in the zinc DNA binding consensus motif (bracketed) are indicated in boldface type. In region c, sequences from T7 DNA polymerase and E. coli DNA polymerase I have been aligned as described in Allison et al. (1985). Identities and similarities between either of the DNA polymerase sequences and the human (Hs) P3 sequence are indicated by colons. In the S. cerevisiae (Sc) P2 sequence, A402 was mutated in a sua8 suppressor (A402R) (Berroteran et al. 1994). In region d, an invariant motif in all multimeric RNA polymerases is indicated above the alignment, with the $\mathrm{D}$ residues involved in $\mathrm{Mg}^{+}$binding (Zaychikov et al. 1996) in boldface type. The shaded and underlined residues in the Sc P3 sequence correspond to the positions of lethal substitutions; the overlined residues correspond to the positions of single or double (indicated by a bracket) conditional mutants (Dieci et al. 1995). N445 was mutated in a sua8 suppressor (N445S) (Berroteran et al. 1994). In the $\mathbf{f}$ region, a putative RNA polymerase III-specific region (Smith et al. 1989a) located upstream of the $\mathbf{f}$ region is indicated in boldface type. The isolated residue in bold indicates a position that is occupied by $\mathrm{N}$ in all of the $\alpha$-amanitin-sensitive enzymes, but not in the $\alpha$-amanitin-resistant enzymes. Residues shaded and underlined in the Sc P3 sequence correspond to the positions of lethal or conditional (indicated in lowercase letters) single, double, or triple alanine scan mutations (Thuillier et al. 1996). The double conditional mutant D829A/R830A in the Sc P3 sequence affects transcription elongation but not transcription complex assembly or formation of the first phosphodiester bond (Thuillier et al. 1996). Residues shaded and underlined in the Mm P2 [L745F, R749P, I779F (Bartolomei and Corden 1995), and N792D (Bartolomei and Corden 1987), mutations], D. melanograster (Dm) P2 [C4 mutation, R741H (Chen et al. 1993)], and C. elegans (Ce) P2 [C777Y/G785E double mutation, cited in Chen et al. (1993)] correspond to the positions of mutations that confer resistance to $\alpha$-amanitin. In region $\mathbf{g}$, a highly conserved stretch of seven amino acids that is part of the $\beta^{\prime}$ region cross-linked to the $3^{\prime}$ end of nascent RNA (Borukhov et al. 1991) is indicated in boldface type. In the Sc P2 sequence, the shaded and underlined T1080 and S1096 residues indicate the positions of mutations (T1080I and S1096F) that affect start site location (Hekmatpanah and Young 1991). In region h, upstream of the conserved region, the shaded and underlined $\mathrm{G}$ residues in the Sc P2 sequence corresponds to the location of a sua8 suppressor (G1388V) (Berroteran et al. 1994). 


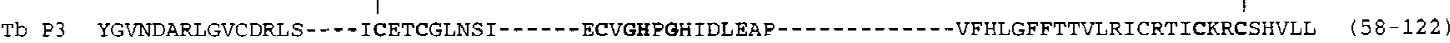

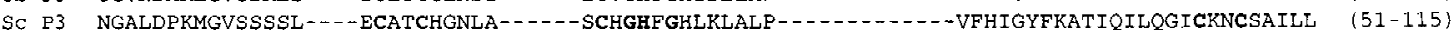

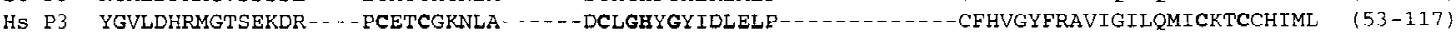
HS P2 GGLMDPRQGVIERTG----RCQTCAGNMT-_-_-ECPGHFGHIELAKP_.........-VFHVGFLVKTMKVLRCVCFECSKLLV (55-119) Mm P2 GGLMDPROGVIERTG----RCQTCAGNMT-_-_-_ECFGHFGHIELAKP-_-_-_-_-_--VFHVGFLVKTMKVLRCVCFFCSKLLV (55-119)

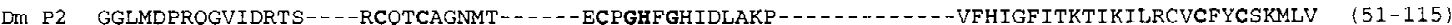
Ce P2 GGLMDPRQGVIDRRG----RCMTCAGNLT-----DCPGHFGHLELAKP-----------VFHIGFLTKTL.KILRCVCFYCGRLLI (49-114) SC P2 GGLNDPRLGSIDRNL----KCQTCQEGMN---.--ECPGHFGHIDLAKP----------VFHVGFIAKIKKVCECVCMHCGKLLL (51-115) Tb P2 GGINDLRMGTTDFEF----ACETCHRKHP--.---ECPGHFGYIELAEP--.--_-_---VFNIGVFDLVLLVLKCVCKTCGALLL (52-116)

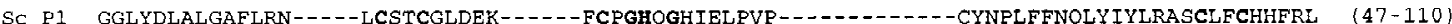
$\mathrm{Tb}$ P1 ATFYDTRMGNFDANPFPPQTCQTCAASLTGKYGNERCHGHFGFVGMPRIRPGSAHSDSDRLVVLNPHLAMDADRLFRAKCFFCHKFRA (70-157) Hh $\mathrm{A}$ MGLMDPRLGVIDPGL----ECKTCGQRSG-----GCNGHFGHIELAAP----------VIHVGFSKLIRRLLRGTCRECASLLL (46-110) $+*+* * * * * *+++$

\section{REGION b}

$\begin{array}{lllll}\text { Tb } & \text { P3 } & \text { SPTDLLMTTLLVPPVPVRP---RGCAGTTTVRDDDLTAQYNDIL } & (254-294) \\ \text { SC } & \text { P3 } & \text { RPETYIWRYLPAPPVCIRPS--VMMQDSPASNEDDLTVKLTEIV } & (252-293) \\ \text { HS P3 } & \text { KPSDLILTRLLVPPLCFRPS--VVSDLKSGTNEDDLTMKLTEII } & (246-287) \\ \text { HS P2 } & \text { RPEWMIVTVLPVFPLSVRPA--VVMQGSAR-NQDDLTHKLADIV } & (244-284) \\ \text { Mm P2 } & \text { RPEWMIVTVLPVPPLSVRPA--VMMGSAR-NQDDLTHKLADIV } & (244-284) \\ \text { Dm P2 } & \text { RPDWMIVTVLPVPPLAVRPA--VMMFGAAK-NQDDLTHKLSDII } & (235-276) \\ \text { Ce P2 } & \text { RPEWMICTVLPVPPLAVRPA--VVTFGSAK-NQDDLTHKLSDII } & (238-278) \\ \text { SC P2 } & \text { RPEWMILTCLPVPPPPVRPS--ISFNESQR-GEDDLTFKLADIL } & (230-270) \\ \text { Tb P2 } & \text { HPRDLVLTVLPVPPPQVRPA--ISFGGLRS--DDELTHQIMSIV } & (239-278) \\ \text { SC P1 } & \text { KADSFFMDVLVPPTRRLPSLGEEVHENSQNQLLSKVLTSL } & (351-410) \\ \text { Tb P1 } & \text { RYKLFFLDRILVPPLPLRLSSGVRVNDNGLIIPDEQTRALSDIL } & (369-412) \\ \text { Hh A } & \text { RFEWMILTVLPVPPVARPS--ITLDNGQR-SEDDLTHKLVDII } & (276-316)\end{array}$

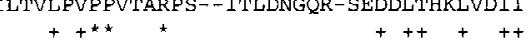

\section{REGION C}

T7 DNA pol EC DNA po11

Tb P3

$S c$ P3

Hs P3

Hs $\mathrm{F} 2$

$\mathrm{Mm}$ F2

Dm P2

Ce F2

SC P2

$\mathrm{Tb} F 2$

Sc P1

Tb P1

A

$E \subset \beta^{\prime}$

\section{$\beta \# 8 \quad \mathrm{~J}$ turn, $\mathrm{K}$}

TGR-ATHAFPNLAQIP-GVRSPYGEQCRDAFQA

TGR-LSSTDPNLQNIP- -VRNEEGRRIRQAFIA

SDLKSYAQRLKSKHGRFRCNLSGKRVDYSGRSVISPDPNLDVDELAVPLHVARVLTYPQRVFKAN---HELMRRLVRNGPHVHPGA KPIRGFCQRLKGKOGRFRGNL SGKRVDFSGRTVISPDPNLSIDEVAVPDRVAKVLTYPEKVTRYN- --RHKLOELIVNGPNVHPGA KWTRGFVQRLKGKQGRFRGNLSGKRVDFSGRTVISPDPNUR IDFVAVPVHVAK I LTF PEKVNKAN--- INFLRKLVQNGPEVHPGA RPLKSLKQRLKGKEGRVRGNLMGKRVDFSARTVITPDPNL SIDQVGVPRS IAANMTFAEIVTPFN - - I IDKLQELVVKGGNSOY PGA RPLKSLKQRL KGKEGRVRGNLMGKRVDFSARTV ITPDPNLS IDQVGVPRS I AANMTFAEIVTPFN - - IDRLOELVRRGNSOYPGA KPLKAIKARLKGKEGR IRGNLMGKRVDFSARTVITPDPNLR IDQVGVPRS IAQNLTFPELVTPFN--- IDRMQELVRRGNSQYPGA KPLKSIKQRLKGKEGR IRGNLMGKRVDFSARTVITADPNLP IDTVGVPRTI AQNLTFPEIVTPFN--- VDKLQELVNRGDTQY PGA R PVKSIRARLKGKEGR IRGNLMGKRVDFSARTVISGDPNLELDQVGVPKS IAKTLTYPEVVTPYN-- - IDRLTQLVRNGPNEHPG KKLKSLTERLKGKYGRLKGNLMGKRVDFSARTVITGDPN IDVDEVGVPFSVAMTLTFPERVNTVN- - -KKRLTEFARR - -TVYPSA VPI PGVKQALEKKEGLFRKHMMGKRVNYAARSVISPDPN IETNEIGVP PVFAVKLTYPEPVTAYN---IAELRQAVINGPDKWPGA EFYAEI VNSFAKKEGLFRMNMMGKRVNOACRSVISPDPFVEPNEVLI.PRPI.ARALSFPEQVTCFAPARMNLLKHCVNNGPRKYPGA

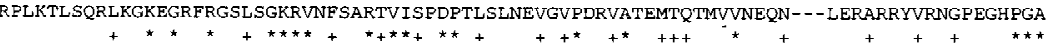
RPLESLADMIKGKOGRFQNLLGKRZDYSGRSVITVGPYLRLHQCGLPKKMALELFKPFIYGKWELRGLATTIKAAKKMVEREEAV
$\{426-457\}$ $(666-695)$

\section{REGION a}

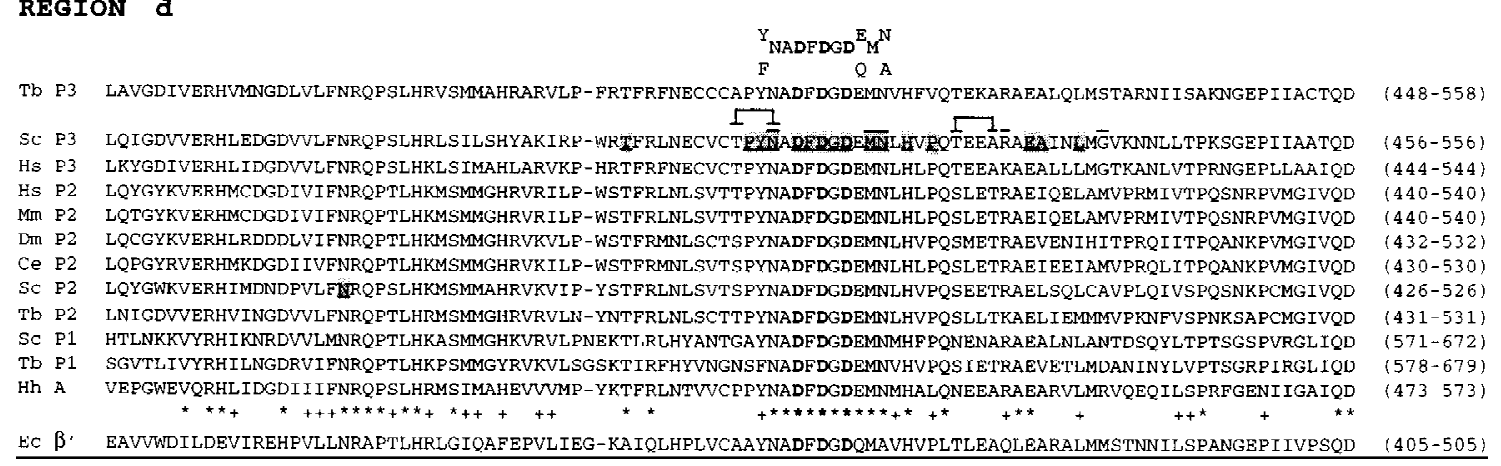

Figure 7 (See p. 1013 for legend.) 


\section{REGION e}

Tb P3 PIPAILKPVELWTGKQ SC P3 PPPAIMKPYYLWTGKQ Hs P3 PPPTILKPVTLWTGKQ HS P2 PQPAILKPRPLWTGKQ Mm P2 PQPAILKPRPLWTGKQ Dm P2 PQPCILKPRPLWTGKQ Ce P2 PQPAILKPKPLWTGKQ SC P2 PTPAIIKPKPLWSGKO $\mathrm{Tb}$ P2 PIPAILKPRPLWTGKQ SC P1 LPPTIFKPYPLWTGKQ Tb P1 PIPAILMPRPMWTGKO

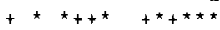

Hh A AAGTDEDGDQYWTGHQ
$(585-600)$

$(593-608)$

$(584-599)$

$(575-590)$

$(575-590)$

$(567-582)$

$(565-580)$

$(561-576)$

$(564-579)$

$(716-730)$

$(724-739)$

$(608-623)$

\section{REGION $\mathbf{f}$}

Tb P3 EARLNTELSKVRDECGTAAVQTLSIHNNTPL IMVQSGSKGSALNIAQMMACVGQ-QTVSGKRILD

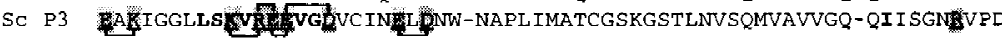
HS P3 EALILKELSVIRDHAGSACLRELDKS-NSPLTMALCGSKGSF INISQMIACVGQ-QAISGSRVPD HS P2 ENQVNR I LNDARDKTGSSAQKSLSEY-NNFKSMVUSGAKGSK INISQVIAVVGQ-QNVEGKR I PF Mm P2 ENQVNRI INDARDKTGSSAQKSLSEY-NNFKSMUVSGAKGSKINISQVIAVVGQ-QWVEGKRIPF DM P2 ENKVNRI INDABDKTTGGSAKKSLTEY-NNLKAMVVSGSKGSNINI SQVI ACVGQ-QNVEGKRI PY Ce P2 ENKVNQILNDARDRTGSSAQKSLSEF-NNFKSMVVSGSKGSKINISQVIAQVGQ-QNVEGKRIPF SC P2 EDNVVRFLNEARDKAGRLAEVNLKDL-NNVKQMVMAGSSKGSF INIAQMSACVGQ-QSVEGKRIAF Tb P2 EADVNSALNKCREEAAKKALSNVRRT-NSFKVMIEAGSKGTDLNICQI AVFVGQ-QNVAGSR I PF SC P1 ESKVNAITSQVVSKCVPDGTMKKFPC-NSMQAMALSGAKGSNVNVSQIMCLLGQ-QALEGRRVPV Tb P1 APMIADYATKIQQEFVPQRMLVPFPK-NHLLLMT ISGAKGSNLNATQMSLQLGQ-QLFDGLRVKR Hh A EMKIMQTLGKARDSAODVAEENFDED-NPAVVMANSGARGSMLNLTQMAGCVGQ-QAVRGERINR $++$

EC $\beta \cdot$ SKAMMDNLQTETVINRDGQEEKQVSF-NSIYMADSGRESAAQIBRLAGMRELAKPDGSIIHE

\section{REGION $\mp$ (cont.)}

Tb P3 AFQDRSLPHFHRFEEAFAARGFVANSFYSGLSPTEFFFHTMAGREGLVDTAVKTAETGY IYRRLMKAMENLSVRYDGTVRNTKGDVIQLRFGEDGLD

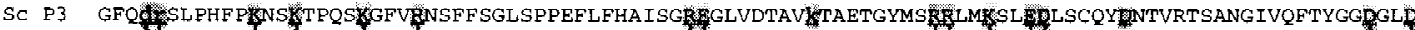
HS P3 GFENRSLPHFEKHSKLPAAKGFVANSFYSGLTPTEFFFHTMAGREGLVDTAVKTAETGYMORRLVKSLEDLCSOYDLTVRSSTGDI IQFIYGGDGLD HS P2 GFKHRTL PHF IKDDYGPESRGFVENSYLAGLTPTEFFFHAMGGREGLIDTAVKTAETGY IQRRLIKSMESVMVYDATVRNS INQVVQLRYGEDGLA Mm P2 GFKHRTL PHF IKDDYGPESRGFVENSYLAGLTPTEFFF HAMGGREGLIDTAVKTAETGY IORRLI KSMESVMVKYDATVRNSINOVVOLRYGEDGLA DM P2 GFRKRTL FHFIKDDYGPESRGEVENSYLAGLTPSEFYFHAMGGREGLIDTAVKTAETGY IQRRLI KAMESVMVNYDITVRNSVGQL IQLRYGEDGLC $\mathrm{Ce}$ P2 GERHRTLPHFIKDDYGPESKGFVENSYLAGLTPSEFFFHAMGGREGLIDTAVKTAETGYIQRRLIKAMESVMVNYDGTVRNSLAQMVQLRYGEDGLD SC P2 GFVDRTLPHFSKDDYSPESKGFVENSYLRGLTPQEFFFHAMGGREGLIDTAVKTAETGY IQRRLVKALEDIMVHYDNTTRNSLGNVIQFIYGEDGMD $\mathrm{Tb}$ P2 GFRRRTLPHFMLDDYGETSRGMANRGYVEGLKPHEFFFHTMAGREGLIDTAVKTSDTGYLORKLIKALEDVHAAYDGTVRNANDELIQFMYGEDGLD SC P1 MVSGKTLPSFKPYETDAMAGGYVKGRFYSGIKPOEYYFHCMAGREGLIDTAVKTSRSGYLORCLTKOLEGVHVSYDNSIRDADGTLVQFMYGGDAID $\mathrm{Tb}$ P1 MNSSKTLPSFFTNEKRARSFGFAMGSFASGIRPAEYTIHAMAGRDGLIDTAVKTSRSGHLQRCLIKGLESLVVHWDRTVRDSNGSVIQFMYGGDGLD

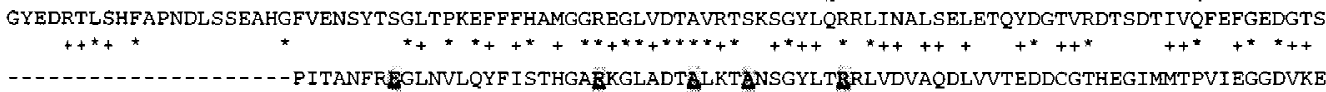

$(748-910)$ $(763-922)$ $(749-908)$ (754-913) $(738-897)$ $(730-889)$ $(728-887)$ $(715-874)$ $(717-876)$ $(897-1056)$ $(895-1054)$ $(755-914)$

$(694-833)$

Ec $\beta$ REGION $g$

Tb P3 PGTPCGAIAAQSVGEPSTOMTLRTFHEAGVASMSITQGVPRLVEVINANRNIATPVVTA SC F3 PGTAIGAIGAQSIGEPGTQMT LKTFHFAGVASMNVTLGVPRI KEI INASKVISTPI INA Hs $\mathrm{P} 3$ PGSAVGALCAQS IGEPGTQMTLKTFHFGGVASMNITLGVPRIKEI INASKAISTPI ITA HS P2 PGEMVGALAAQSLGEPATQMTLNTFHYAGVSAKNVTLGVPRLKELINISKKPKTPSLTV $M m$ P2 PGEMVGALAAQSLGEPATQMTLNTFHYAGVSAKNVTLGVPRLKELINISKKPKTPSLTV DIn P2 PGEMVGALAAQSLGEPATOMTLNTFHFAGVSSKNVTLGVFRLKEI INISKKPKAPSLTV Ce P2 PGEMVGALAAQSLGEPATQMTLNTFHYAGVSAKNVTLGVPRLKEI INVSKTLKTFSLTV SC P2 PGEMVGVLAAQS IGEPATQMELNTFHFAGVASKKVTSGVPRLKEILNVAKNMKTPSLTV Tb P2 PGENIGAIAAQSCGEFATQMTLNTFHNAGISSKNVTLGVPRLLELLNVSRNQKHASMTV SC P1 PGEAVGIIASQSVGEPSTQMTLNTFHFAGHGAANVTLGI PRLRE IVMTASA.A IKT POMT Tb P1 PGEPVGLLAAQAAGEPSTQMTLNTFHTAGSTVSHVTEGIPRLRELLIYASVNKAAVVVP th $C$ PLDPVGTVSAQSIGEPGTQMTMNTFHYAGVAEMDVTQGLPRLIELVDARKTPDTPVMEV

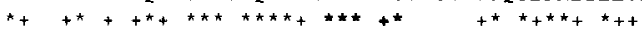

EC $\beta$, KGEAIGVIAAQSIGEPGTQLTMBFFIIIGGAASRAAAESSIQVKNKGSIKLSNVKSVVNS
$(1141-1198)$

$(1085-1142)$

(1029-1087)

$(1099-1157)$

$(1083-1140)$

$(1075-1133)$

(1083-1141)

$(1060-1117)$

$(1080-1137)$

(1181-1239)

$(1196-1254)$

$(59-117)$

$(911-969)$

\section{REGION h}

Tb P3 $\overline{\text { GIQKM--N-FNVLTMASFERTTDHLYNAAATQRVDRDLSVSDSIIVGKPVPLGTTSFDLLLD }}$ SC P3 GLSKM--R-DSVLQLASFEKTTDHLFDAAFYMKKDAVEGVSECI ILGQTMSIGTGSFKVVKC HS P3 GLAKM--K-ESVLMLASFEKTADHLFDAAYFGOKDSVCGVSECI IMGI PMNIGTGLFKLLHK Hs P2 GVNRQ--D-TGPLMKCSFEETVDVLMEAAAHGESDPMKGVSENIMLGQLAPAGTGCFDLLLD Mm P2 GVNRQ--D-TGPLMKCSFEETVDVLMEAAAHGESDPMKGVSENIMLGQLAPAGTGCFDLLLD DM P2 GINRQ--D-TGALMRCSFEETVDVLMDAAAHAETDPMRGVSENI IMGQLPKMGTGCFDLLID Ce P2 GINRQ--E-VGALMRCSFEETVDI LMEAAVHAEEDPVKGVSENIMLGQLARCGTGCFDLVLD SC P2 GNRS--N-TGALMRCSFEETVEILFEAGASAELDDCRGVSENVILGQMAPIGTGAFDVMID Tb P2 GINRS--DTSGFLMRCSFEETVKVLMAAASFGECDPVRGVSANLVLGNQARVGTGLFDLVLN SC P1 GMETS--T-SSFMKMSYETTCQFLTKAVLDNEREQLDSPSARIVVGKLNNVGTGSFDVMWDQ Tb P1 GVIST--S-ASPLFOMTFASSKRWLHRAVSRGMSDDLESFSSAIMVGERPRVGTASVRLSTD Hh $C$ GISGN--K-NSVLARAAFEVTVNHLLDAAIHGESDDLDGVIENVIVGKPVRLGTGDVDLRMC

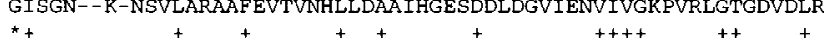

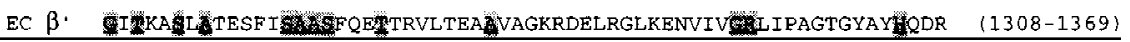

(1428-1486) (1375-1433) $(1308-1366)$ $(1434-1492)$ (1418-1476) $(1413-1471)$ $(1388-1446)$ (1414-1472 (1602-1650) $(1710-1768)$ $(333-391)$ (1410-1468)

Figure 7 (Continued) 
served in all RNA polymerases, and like the sua8 suppressors in the $\mathbf{c}$ and $\mathbf{d}$ regions (see above), the position of the sua8 suppressor in the $\mathbf{h}$ region is conserved in all RNA polymerases aligned. This suggests that these regions play a general, rather than an RNA polymerase II-specific, role in transcription initiation. Both the $\mathbf{g}$ and $\mathbf{h}$ regions are the sites of mutations in the $\beta^{\prime}$ subunit of the E. coli enzyme (shaded and underlined) that alter transcription termination (Weilbaecher et al. 1994), and several of these positions are conserved. Most strikingly, re gion $\mathbf{g}$ contains a stretch of seven highly conserved amino acids (indicated in boldface type), which is part of a larger region of the $\beta^{\prime}$ subunit of E. coli RNA polymerase that could be cross-linked to the $3^{\prime}$ end of nascent RNA (Borukhov et al. 1991). The high conservation of this stretch suggests that it performs the same function in all enzymes, including the human RNA polymerase III enzyme.

These studies show that the largest subunit of human RNA polymerase III is highly related to the largest subunit of RNA polymerase III from other species and, to a lesser extent, to the largest subunit of RNA polymerases II and I. It is striking, however, that the greater degree of conservation among RNA polymerase III largest subunits cannot be attributed to clusters of conserved residues. With the possible exception of the small cluster of amino acids at the end of region d K/RXGEPI/LI/LA, which may form an RNA polymerase III-specific motif, the greater sequence conservation among the RNA polymerase III largest subunit sequences reflects isolated identities. This suggests that the specific recruitment of RNA polymerase I, II, or III to its various target promoters will involve either subunits that are unique to each RNA polymerase (Werner et al. 1993; Khoo et al. 1994), or subtle differences in protein-protein interactions involving isolated amino acid differences.

\section{METHODS}

\section{Isolation of CDN A Clones Encoding the Largest} Subunit of RNA Polymerase III

The largest RNA polymerase III subunit has been cloned from four organisms: The protozoans P. falciparum (Li et al. 1991), G. Iamblia (Lanzendoerfer et al. 1992), and T. brucei (Smith et al. 1989a) and the yeast S. cerevisiae (Allison et al. 1985). Alignment of the four predicted amino acid sequences showed two highly conserved stretches in the $\mathbf{f}$ and $\mathbf{g}$ regions. We first designed two nested forward primers corresponding to the sequences AQSVGEP and GEPSTQMT, respectively, and a reverse primer corresponding to the sequence AGVASM, at both ends of the conserved stretch in region $\mathbf{g}$ of the $T$. brucei sequence. In the first round of PCR, we used a 5' end-labeled outside forward primer together with the reverse primer. The products of the PCR were fractionated on a sequencing gel, the region of the gel corresponding to the expected size product was excised, and the nucleic acids were eluted and used as a template for a second PCR reaction with the internal forward primer and the same reverse primer as in the first PCR reaction. The products were fractionated on a $20 \%$ nondenaturing polyacrylamide gel and stained with ethidium bromide. We obtained a clearly visible band of the expected size, which was subcloned and sequenced. The sequence did not correspond to the al ready cloned largest subunit of human RNA polymerase II (Wintzerith et al. 1992) and could thus correspond to the largest subunit of either RNA polymerase I or RNA polymerase III. We used the sequence information thus obtained to design two exact nested reverse primers. These were used in two successive PCRs with two degenerate nested primers corresponding to the sequences VDTAVKT and VKTAET, respectively, in region $\mathbf{f}$ of the T. brucei sequence. We obtained a partial cDNA corresponding to amino acids V863-F1055 in the sequence shown in Figure 1. We then used this partial cDNA as a probe to screen a human igt10 cDNA library from NTera2D1 cells (Skowronski et al. 1988) and obtained a longer cDNA. A 300-bp probe corresponding to the amino terminus of the ORF encoded by this cDNA was then used for a second screening. The procedure was repeated two more times to obtain a cDNA encoding amino acids V185-T1391 in Figure 1.

To obtain sequences encoding the amino terminus of the protein, we performed 5' RACE, as described (Frohman 1993), from total HeLa RNA, except that we used the enzyme SuperScript II RT (GIBCO BRL) for the reverse transcription. We obtained a fragment encoding the missing amino-terminal amino acids and an additional $20 \mathrm{bp}$ upstream of the putative start methionine. To confirm the sequence obtained by $5^{\prime}$ RACE, we then performed a PCR with CDNA made from total HeLa RNA using a forward primer corresponding to the 5 ' end of the DNA sequence in combination with a reverse primer corresponding to the $3^{\prime}$ end of the RACE fragment. The sequence matched that obtained by RACE except at position 84, where an $A \rightarrow G$ change in the DNA sequence led to an arginine to a glycine change. The glycine is part of a highly conserved zinc-binding motif. The sequence in Figure 1 corresponds to the sequence obtained by PCR.

\section{Generation of A ntipeptide A ntibodies}

A peptide corresponding to the carboxyl terminus of the protein (see Fig. 1) was synthesized, coupled to keyhole hemocyanin (KLH, Pierce Molecular Biology Products) as described (Harlow and Lane 1988), and injected into rabbits to generate a polyclonal antipeptide antibody (antibody $\alpha$-CSH499, rabbit CS377).

\section{Partial Purification of Human RNA Polymerase III}

To follow RNA polymerase III activity during purification, we used a modification of the nonspecific transcription assay described previously (Roeder 1974). An amount of $31 \mu \mathrm{l}$ of a buffer containing $60 \mathrm{mM}$ Tris/ $\mathrm{HCl},(\mathrm{pH} 7.9), 2 \mathrm{mM} \mathrm{MnCl}, 2$ $\mathrm{mm} \mathrm{MgCl}_{2}, 0.6 \mathrm{~mm}$ GTP, CTP, and ATP, $0.05 \mathrm{~mm}$ UTP, $1 \mu \mathrm{Ci}$ [5,6- $\left.{ }^{3} \mathrm{H}\right]$ UTP (44 Ci/mmole, Amersham), $2.5 \mu \mathrm{g}$ of poly [d(AT)], and $16 \mathrm{~mm} \mathrm{AmSO}_{4}$ was added to $20 \mu \mathrm{l}$ of fraction in buffer D (20 mM HEPES/KOH at pH 7.9, $100 \mathrm{~mm} \mathrm{KCl,} \mathrm{20 \%} \mathrm{glycerol,}$ $0.2 \mathrm{~mm}$ EDTA) containing $3 \mathrm{~mm}$ DTT. To distinguish between 
RNA polymerase I, II, and III activity, the reactions were supplemented with either no, $2 \mu \mathrm{g} / \mathrm{ml}$, or $300 \mu \mathrm{g} / \mathrm{ml}$ of $\alpha$ amanitin. The reactions were then incubated for $20 \mathrm{~min}$ at $30^{\circ} \mathrm{C}$ after which they were pipetted onto DEAE-cellulose disks (Whatman DE81). The disks were then washed five times in $0.5 \mathrm{M} \mathrm{Na}_{2} \mathrm{HPO}_{4}$, twice in $\mathrm{H}_{2} \mathrm{O}$, and twice in $100 \%$ EtOH. The incorporation of $\left[5,6-{ }^{3} \mathrm{H}\right] U T \mathrm{P}$ into the nascent RNA was then measured by scintillation counting.

To obtain fractions enriched in RNA polymerase III, 850 $\mathrm{ml}$ of HeLa S100 extract (Dignam et al. 1983) (12 mg/ml, 10.2 grams of protein) was used as starting material for sequential ammonium sulfate precipitations. The $30 \%-40 \%$ ammonium sulfate precipitate, which contained RNA polymerase III, was redissolved in $300 \mathrm{ml}$ of buffer $D$ supplemented with $3 \mathrm{~mm}$ DTT and $0.1 \mathrm{~mm}$ PMSF and dialyzed against the same buffer. An amount of $100 \mathrm{ml}$ of the ammonium sulfate cut (1950 mg of protein) was then loaded onto a 174-ml P11 column (11-12 $\mathrm{mg}$ of protein $/ \mathrm{ml}$ of packed resin) equilibrated in buffer $D$ containing $3 \mathrm{~mm}$ DTT and $0.5 \mathrm{~mm}$ PMSF. Material was eluted with a four column volume linear gradient from 0.1 to $1 \mathrm{M}$ $\mathrm{KCl}$ in buffer $\mathrm{D}$ at a flow rate of 0.7 column volume/hr. RNA polymerase III eluted between 0.5 and $0.6 \mathrm{M} \mathrm{KCl}$. The fractions containing the peak of RNA polymerase III activity were pooled (90 ml, $129 \mathrm{mg}$ of protein), dialyzed against buffer $D$ containing $3 \mathrm{~mm}$ DTT and $0.5 \mathrm{~mm}$ PMSF, and used for the immunoprecipitations and immunoblot analyses. Protein concentrations were measured by the Bradford assay.

\section{Immunoblots}

The full-length ORF of the human RNA polymerase III largest subunit (designated hRPC155) was cloned into a modified pCITE vector ( $\mathrm{PCITE} \mathrm{M} 1$ ) with standard cloning techniques to generate the construct $\mathrm{pCITE}-\mathrm{hRPC} 155$. One microgram of plasmid was used as template for coupled in vitro transcription-translation assays (TNT, Promega) in a final volume of $50 \mu$ l containing $4 \mu \mathrm{l}$ of $\mathrm{L}-\left[{ }^{35} \mathrm{~S}\right]$ methionine. Five microliters of pCITE-hRPC 155-programmed lysate, $5 \mu$ l of unprogrammed, $10 \mu \mathrm{l}$ of P11 fraction, and a mixture of $10 \mu \mathrm{l}$ of P11 and $5 \mu \mathrm{l}$ of programmed lysate were loaded on a $7.5 \%$ SDSpolyacrylamide gel. The gel was then blotted onto nitrocellulose (Whatman), and the membrane was probed with rabbit $\alpha-\mathrm{CSH} 499$ antibodies at a 1:1000 dilution. The signals were visualized by chemiluminescence (ECL, Amersham). After extinction of the chemiluminescent signal, the membrane was re-exposed to X-ray film for $8 \mathrm{hr}$ to visualize the L${ }^{35}$ S]methionine-labeled, in vitro-translated proteins.

\section{Immunoprecipitation of A ctive RN A Polymerase III}

Rabbit preimmune and $\alpha$-CSH499 antibodies were chemically cross-linked to protein A-Sepharose beads as described (Harlow and Lane 1988). One hundred microliters of beads was incubated for $30 \mathrm{~min}$ at $4^{\circ} \mathrm{C}$ with $1 \mathrm{ml}$ of RNA polymerase III-enriched P11 fraction. The beads were then washed three times with $1 \mathrm{ml}$ of buffer D containing $0.1 \%$ Tween $20,1 \mathrm{~mm}$ DTT, and $0.5 \mathrm{~mm}$ PMSF. The enzyme was then eluted off the beads by incubation of the beads in $100 \mu$ l of buffer D containing $1 \mu \mathrm{g} / \mu \mathrm{l}$ of either specific (CSH499) or nonspecific (CSH498) peptide. The beads were then pelleted, and $20 \mu \mathrm{l}$ of the supernatant was used in the nonspecific transcription assay described above.

\section{In Vitro Transcription}

Forty microliters of whole cell extract (Maroney et al. 1990) was incubated with an equal volume of preimmune or $\alpha$ CSH499 beads. Where indicated, the incubations were performed in the presence of $4 \mu \mathrm{g}$ of the specific blocking peptide (CSH499) or of a nonspecific peptide (CSH498). Four microliters of untreated or treated extract was then programmed with either $0.25 \mu \mathrm{g}$ of the plasmid pBSM 13+ VAl (Lobo et al. 1992) containing the Ad2 VAl gene, or $0.5 \mu \mathrm{g}$ of the plasmid p119ML(CA2) (Lobo et al. 1992) containing the Ad2 major late promoter in front of a G-less cassette. The reactions were performed in a total volume of 20 or $30 \mu \mathrm{l}$, respectively, under the conditions described (Lobo et al. 1992).

\section{A CKN O WLEDG MENTS}

We thank B. Ma for help with the sequencing of hRPC155, S. Teplin for synthesis of oligonucleotides, J.P.J. Chong for help with the sequence alignments and discussion, and R.W. Henry for helpful discussions during the entire course of this work. We also thank J.P.J. Chong and R.W. Henry for comments on the manuscript, and M. Ockler, J. Duffy, and P. Renna for artwork and photography. This work was funded in part by National Institutes of Health grant R01GM 38810.

The publication costs of this article were defrayed in part by payment of page charges. This article must therefore be hereby marked "advertisement" in accordance with 18 USC section 1734 solely to indicate this fact.

\section{REFEREN CES}

Ahearn, J.M., M.S. Bartolomei, M.L. West, L.J. Cisek, and J.L. Corden. 1987. J. Biol. Chem. 262: 10695-10705.

Allison, L.A., M. Moyle, M. Shales, and C.J. Ingles. 1985. Extensive homology among the largest subunits of eucaryotic and procaryotic RNA polymerases. Cell 42: 599-610.

Baer, M., T.W. Nilsen, C. Costigan, and S. Altman. 1989. Structure and transcription of a human gene for H1 RNA, the RNA component of human RNase P. Nucleic Acids Res. 18: $97-103$.

Bartolomei, M.S. and J.L. Corden. 1987. Localization of an $\alpha$-amanitin resistance mutation in the gene encoding the largest subunit of mouse RNA polymerase II. Mol. Cell. Biol. 7: 586-594.

1995. Clustered $\alpha$-amanitin resistance mutations in mouse. Mol. \& Gen. Genet. 246: 778-782.

Baumann, P., S.A. Qureshi and S.P. Jackson. 1995.

Transcription: New insights from studies on Archae. Trends Genet. 11: 279-283.

Berroteran, R.W., D.E. Ware, and M. Hampsey. 1994. The sua8 suppressors of Saccharomyces cerevisiae encode replacements of conserved residues within the largest subunit of RNA polymerase II and affect trasncription start site selection similarly to sua7 (TFIIB) mutations. Mol. Cell. Biol. 14: 226-237. 
Bird, D.M. and D.L. Riddle. 1989. Molecular cloning and sequencing of ama-1, the gene encoding the largest subunit of Caenorhabitis elegans RNA polymerase II. Mol. Cell. Biol. 9: 4119-4130.

Borukhov, S., J. Lee, and A. Goldfarb. 1991. Mapping of a contact for the RNA 3' terminus in the largest subunit of RNA polymerase. J. Biol. Chem. 266: 23932-23935.

Buratowski, S. and H. Zhou. 1992. A suppressor of TBP mutations encodes an RNA polymerase III transcription factor with homology with TFIIB. Cell 71: 221-230.

Chamberlin, M.J. 1992. New models for the mechanism of transcription elongation and its regulation. In The Harvey lectures, series 88, pp. 1-21. Wiley-Liss, New York, NY.

Chan, C.L. and R. Landick. 1994. New perspectives on RNA chain elongation and termination by E. coli RNA polymerase. Transcription: Mechanisms and regulation. (eds. R.C. Conaway and J.W. Conaway), pp. 297-321. Raven Press, New York, NY.

Chen, Y., J. Weeks, M.A. Mortin, and A.L. Greenleaf. 1993. Mapping mutations in genes encoding the two large subunits of Drosophila RNA polymerase II defines domains essential for basic transcription functions and for proper expression of developmental genes. Mol. Cell. Biol. 13: 4214-4222.

Cochet-Meilhac, M. and P. Chambon. 1974. Animal DNA-dependent RNA polymerases. II. Mechanism of the inhibition of RNA polymerase $B$ by amatoxins. Biochim. Biophys. Acta 353: 160-184.

Colbert, T. and S. Hahn. 1992. A yeast TFIIB-related factor involved in RNA polymerase III transcription. Genes \& Dev. 6: 1940-1949.

Coulter, D.E. and A.L. Greenleaf. 1985. A mutation in the largest subunit of RNA polymerase II alters RNA chain elongation in vitro. J. Biol. Chem. 260: 13190-13198.

de Mercoyrol, I., C. Job, and D. Job. 1989. Studies on the inhibition by $\alpha$-amanitin of single step addition reactions and productive RNA synthesis catalysed by wheat germ RNA polymerase II. Biochem. J. 258: 165-169.

Dieci, G., S. Hermann-Le Denmat, E. Lukhtanov, P. Thuriaux, M. Werner, and A. Sentenac. 1995. A universally conserved region of the largest subunit participates in the active site of RNA polymerase III. EMBO J. 14: 3766-3776.

Dietrich, M.A., J.P. Prenger, and T.J. Guilfoyle. 1990. Plant Mol. Biol. 15: 207-223.

Dignam, J.D., R.M. Lebovitz, and R.G. Roeder. 1983. Accurate transcription initiation by RNA polymerase II in a soluble extract from isolated mammalian nuclei. Nucleic Acids Res. 11: 1475-1489.

Evers, R., A. Hammer, J. Koeck, J. Waldemar, P. Borst, S. Memet, and A.W.C.A. Cornelissen. 1989. Trypanosoma brucei contains two RNA polymerase III largest subunit genes with an altered c-terminal domain. Cell 56: 585-597.

Frohman, M.A. 1993. Rapid amplification of complementary cDNA ends for generation of full-length complementary DNAs: Thermal RACE. Methods Enzymol. 218: $340-356$.

Ha, I., S. Roberts, E. Maldonado, X. Sun, M. Green, and D. Reinberg. 1993. Multiple functional domains of human transcription factor IIB. Distinct interactions with two general transcription factors and RNA polymerase II. Genes \& Dev. 7: 1021-1032.

Harlow, E. and D. Lane. 1988. Antibodies: A laboratory manual. Cold Spring Harbor Laboratory, Cold Spring Harbor, NY.

Hekmatpanah, D.S. and R.A. Young. 1991. Mutations in a conserved region of RNA polymerase II influence the accuracy of mRNA start site selection. Mol. Cell. Biol. 11: 5781-5791.

Jokerst, R.S., J.R. Weeks, W.A. Zehring, and A.L. Greenleaf. 1989. Analysis of the gene encoding the largest subunit of RNA polymerase II in Drosophila. Mol. \& Gen. Genet. 215: 266-275.

Khoo, B., B. Brophy, and S.P. Jackson. 1994. Conserved functional domains of the RNA polymerase III general transcription factor BRF. Genes \& Dev. 8: 2879-2890.

Lanzendoerfer, M., P. Palm, B. Grampp, D.A. Peattie and W. Zillig. 1992. Nucleotide sequence of the gene encoding the largest subunit of the DNA-dependent RNA polymerase III of Giardia lamblia. Nucleic Acids Res. 20: 1145.

Leffers, H., F. Gropp, F. Lottspeich, W. Zillig, and R.A. Garrett. 1989. Sequence, organization, transcription and evolution of RNA polymerase subunit genes from the archaebacterial extreme halophiles Halobacterium halobium and Halococcus morrhuae. J. Mol. Biol. 206: 1-17.

Li, W.-B., D.J. Bzik, M. Tanaka, H. Gu, B.A. Fox, and J. Insel burg. 1991. Characterization of the gene encoding the largest subunit of Plasmodium falciparum RNA polymerase III. Mol. Biochem. Parasitol. 46: 229-239.

Lobo, S.M., M. Tanaka, M.L. Sullivan, and N. Hernandez. 1992. A TBP complex essential for transcription from TATA-less but not TATA-containing RNA polymerase III promoters is part of the TFIIIB fraction. Cell 71: 1029-1040.

López-De-León, A., M. Librizzi, K. Puglia, and I.M. Willis. 1992. PCF4 encodes an RNA polymerase III transcription factor with homology to TFIIB. Cell 71: 211-220.

Maroney, P.A., G.J. Hannon, and T.W. Nielsen. 1990. Transcription and cap trimethylation of a nematode spliced leader RNA in a cell-free system. Proc. Natl. Acad. Sci. 87: 709-713.

Memet, S., M. Gouy, C. Marck, A. Sentenac, and J.-M. Buhler. 1988a. RNA polymerases B and C are more closely 
related to each other than to RNA polymerase A. J. Biol. Chem. 263: 2830-2839.

1988b. RPA190, the gene coding for the largest subunit of yeast RNA polymerase A. J. Biol. Chem. 263: 10048-10051.

Mital, R., R. Kobayashi, and N. Hernandez. 1996. RNA polymerase III transcription from the human U6 and Adenovirus type $2 \mathrm{VAl}$ promoters has different requirements for human BRF, a subunit of human TFIIIB. Mol. Cell. Biol. 16: 7031-7042.

Murphy, S., M. Tripodi, and M. Melli. 1986. A sequence upstream from the coding region is required for the transcription of the 7SK RNA genes. Nucleic Acids Res. 14: 9243-9260.

Ollis, D.L., P. Brick, R. Hamlin, N.G. Xuong, and T.A. Steitz. 1985a. Structure of the large fragment of Escherichia coli DNA polymerase I complexed with dTMP. Nature 313: 762-766.

Ollis, D.L., C. Kline, and T.A. Steitz. 1985b. Domain of E. coli DNA polymerase I showing sequence homology to T7 DNA polymerase. Nature 313: 818-819.

Ovchinnikov, Y.A., G.S. Monastyrskaya, V.V. Gubanov, S.O. Guryev, I.S. Salomatina, T.M. Shuvaeva, V.M. Lipkin, and E.D. Sverdlov. 1982. The primary structure of E. coli RNA polymerase, nucleotide sequence of the rpoC gene and amino acid sequence of the $\beta^{\prime}$ subunit. Nucleic Acids Res. 10: $4035-4044$.

Puhler, G., H. Leffers, F. Gropp, P. Palm, H.-P. Klenk, F. Lottspeich, R.A. Garrett, and W. Zillig. 1989. Archaebacterial DNA-dependent RNA polymerases testify to the evolution of the eucaryotic nuclear genome. 86: 4569-4573.

Roeder, R.G. 1974. Multiple forms of deoxyribonucleic acid-dependent ribonucleic acid polymerase in $\mathrm{X}$ enopus laevis. J. Biol. Chem. 249: 241-248.

Schultz, L.D. and B.D. Hall. 1976. Transcription in yeast: $\alpha$-Amanitin sensitivity and other properties which distinguish between RNA polymerases I and III. Proc. Natl. Acad. Sci. 73: 1029-1033.

Sentenac, A., M. Riva, P. Thuriaux, J.-M. Buhler, I. Treich, C. Carles, M. Werner, A. Ruet, C. Mann, N. Chiannilkulchai, S. Stettler, and S. Mariotte 1992. Yeast RNA polymerase subunits and genes. In Transcriptional regulation (ed. S.L. McKnight and K.R. Yamamoto), pp.27-54. Cold Spring Harbor Laboratory Press, Cold Spring Harbor, NY.

Skowronski, J., T.G. Fanning, and M.F. Singer. 1988. Unit Length LINE-1 transcripts in human teratocarcinoma cells. Mol. Cell. Biol. 8: 1385-1397.

Smith, J.L., J.R. Levin, and N. Agabian. 1989a. Molecular characterization of the trypanosoma brucei RNA polymerase I and III largest subunit genes. J. Biol. Chem.

264: 18091-18099.

Smith, J.L., J.R. Levin, C.J. Ingles, and N. Agabian. 1989b. In trypanosomes the homolog of the largest subunit of RNA polymerase II is encoded by two genes and has a highly unusual C-terminal structure. Cell 56: 815-827.

Thompson, J.D., D.G. Higgins, and T.J. Gobson. 1994. CLUSTAL W: Improving the sensitivity of progressive multiple sequence alignment through sequence weighting, position-specific gap penalties and weight matrix choice. Nucleic Acids Res. 22: 4673-4680.

Thuillier, V., I. Brun, A. Sentenac, and M. Werner. 1996. Mutations in the $\alpha$-amanitin conserved domain of the largest subunit of yeast RNA polymerase III affet pausing, RNA cleavage and transcriptional transitions. EMBO J. 15: 618-629.

Thuriaux, P. and A. Sentenac. 1992. Yeast nuclear RNA polymerases. The molecular biology of the yeast Saccharomyces cerevisiae: Gene expression (ed. E.W. Jones, J.R. Pringle, and J.R. Broach), pp. 1-48. Cold Spring Harbor Laboratory Press, Cold Spring Harbor, NY.

Topper, J.N. and D.A. Clayton. 1990. Characterization of human MRP/Th RNA and its nuclear gene: Full length MRP/Th RNA is an active endoribonuclease when assembled as an RNP. Nucleic Acids Res. 18: 793-799.

Wang, Z. and R.G. Roeder. 1995. Structure and function of a human transcription factor TFIIIB subunit that is evolutionarily conserved and contains both TFIIB and high-mobility-group protein 2-related domains. Proc. Natl. Acad. Sci. 92: 7026-7030.

Weilbaecher, R., C. Hebron, G. Feng, and R. Landick. 1994. Termination-altering amino acid substitutions in the $\beta^{\prime}$ subunit of Escherichia coli RNA polymerase identify regions involved in RNA chain elongation. Genes \& Dev. 8: 2913-2927.

Werner, M., S. Hermann-Le Denmat, I. Treich, A. Sentenac, and P. Thuriaux. 1992. Effect of mutations in a zinc-binding domain of yeast RNA polymerase $C$ (III) on enzyme function and subunit association. Mol. Cell. Biol. 12: 1087-1095.

Werner, M., N. Chaussivert, I.M. Willis, and A. Sentenac. 1993. Interaction between a complex of RNA polymerase III subunits and the 70-kDa component of transcription factor IIIB. J. Biol. Chem. 268: 20721-20724.

Wintzerith, M., J. Acker, S. Vicaire, M. Vigneron, and C. Kedinger. 1992. Complete sequence of the human RNA polymerase II largest subunit. Nucleic Acids Res. 20: 910.

Wolin, S.L. and J.A. Steitz. 1983. Genes for two small cytoplasmic Ro RNAs are adjacent and appear to be single-copy in the human genome. Cell 32: 735-744.

Zaychikov, E., E. Martin, L. Denissova, M. Kozlov, V. Markovtsov, M. Kashlev, H. Heumann, V. Nikiforov, A. Goldfarb, and A. Mustaev. 1996. Mapping of catalytic residues in the RNA polymerase active center. Science 273: 107-109.

Received July 7, 1997; accepted in revised form August 27, 1997. 


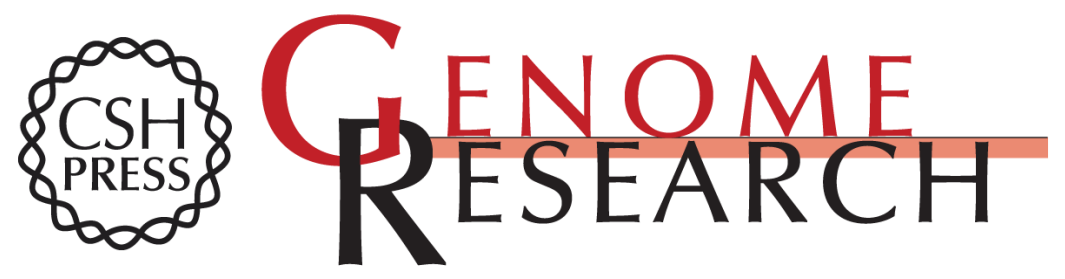

\section{The Largest Subunit of Human RNA Polymerase III Is Closely Related to the Largest Subunit of Yeast and Trypanosome RNA Polymerase III}

Setareh Sepehri and Nouria Hernandez

Genome Res. 1997 7: 1006-1019

Access the most recent version at doi:10.1101/gr.7.10.1006

References This article cites 52 articles, 25 of which can be accessed free at: http://genome.cshlp.org/content/7/10/1006.full.html\#ref-list-1

\section{License}

Email Alerting

Receive free email alerts when new articles cite this article - sign up in the box at the Service top right corner of the article or click here.

\section{Affordable, Accurate Sequencing.}

